\title{
Eyes on the Ballot: Priming Effects and Ethnic Voting in the Developing World
}

\author{
Jeffrey Conroy-Krutz \\ Department of Political Science \\ Michigan State University \\ conroyk6@msu.edu \\ Devra Moehler \\ Annenberg School for Communication \\ University of Pennsylvania \\ dmoehler@asc.upenn.edu
}

The authors made equal contributions to this project. We would like to thank Diana Mutz and Robin Pemantle for their help in designing analytical strategies for this paper; Rosario Aguilar Pariente, our co-researcher in aspects of this project relating to data collection and party-based voting; and André Blais, Joseph Cappella, Monica Schneider, Karleen Jones West, Susanna Wing, and attendees at talks at Michigan State University, the 2012 Midwest Political Science Association Annual Meeting, 2012 African Studies Association Annual Meeting, and the 2013 Pre-APSA Workshop on Electoral Integrity for helpful comments. We would also like to thank John Kavuma, James Odongo, Jin Woo Kim, and Douglas Allen for their assistance with the research, and the University of Pennsylvania Annenberg School for financial support. Fieldwork for Dr. Conroy-Krutz was facilitated by a grant from the National Science Foundation (SES1024031). All remaining errors and omissions are our own. 


\section{Introduction}

While most countries hold elections, there is significant diversity in how citizens vote. Electoral institutions determine whether voters choose between parties or individuals, and whether they make one or multiple choices per office. Voters also interact with ballots in different ways; they might use pens, styluses, inked fingers, or touch screens.

Yet another source of variation is the manner in which the choices are displayed. Morelimited ballot designs include only text indicating candidates' names or parties. In other instances, there is more textual information, such as candidates' mailing addresses or occupations. And visual features, such as party symbols and candidate images, are prominent on many ballots, especially in the developing world (Reynolds \& Steenbergen 2006). Advocates maintain that images facilitate voting by those with limited literacy, access to information, or previous voting experience (Smith et al. 2009). When images are present, such thinking goes, voters simply need to remember their favored candidate's face or party's symbol.

While designing voting technologies that accurately record preferences is important, ${ }^{1}$ it is also necessary to consider that certain information and images on ballots could have (presumably) unintended consequences. Namely, these elements might affect voting, not only by helping voters locate preferred choices, but also by shaping those preferences. For example, parties' symbols could provoke certain emotions or prime certain considerations [publication by authors]. There is also substantial research to suggest that photographs on ballots might affect voter preferences. For example, candidates' appearance might affect outcomes, with those

\footnotetext{
${ }^{1}$ For research, see Ansolabehere \& Stewart 2005; Carman et al. 2008; Herrnson et al. 2012; Herron \& Wand 2007; Reynolds \& Steenbergen 2006; and Wand et al. 2001.
} 
perceived to be more attractive performing better (Banducci et al. 2008; Buckley et al. 2007; Johns \& Shephard 2011).

Another way that ballot photographs could affect electoral outcomes - and one that has, to our knowledge, not been studied - is by influencing rates of ethnic voting. We expect that such photographs will increase the likelihood that individuals vote for coethnics, when such candidates are available and in contexts in which ethnicity is politically relevant. Further, these effects can occur because photographs prime identity-based considerations.

This expectation stems from the fact that ballot photographs contain a critical feature: eyes. A growing body of literature suggests that individuals' behavior can be affected by images of eyes "observing" them, even when it is clear that no actual humans can see their actions (Bateson et al. 2013; Burnham \& Hare 2007). This "watching eyes" effect operates in consistent ways, with subjects exhibiting more pro-social behavior or actions in compliance with prevalent norms (Nettle et al. 2012), such as making larger donations in behavioral games (Burnham 2003; Burnham \& Hare 2007; Haley \& Fessler 2005; Nettle et al. 2012) or to actual charities (Ekström 2011; Powell et al. 2012) when in the presence of images of eyes. In settings where support for ascriptive groups is rewarded and expected, "watching eyes" could stimulate in-group loyalty. In other words, ballot photographs can prime individuals to weight identity-based considerations more heavily in their electoral decision-making, resulting in higher rates of coethnic voting.

We conducted an experiment to test the effects of ballot photographs on ethnic voting in Uganda, just days prior to 2011 elections. Subjects marked different types of randomly assigned 
mock ballots featuring actual candidates for two offices-Member of Parliament (MP) and local district chairperson — with some ballots including candidate photographs. ${ }^{2}$

We find that photographs did significantly affect ethnic-voting rates: subjects who received ballots containing candidate photographs voted for $27.0 \%$ more coethnics than those whose ballots lacked them. Further, our results suggest that these effects occurred because photographs primed ethnic considerations, as subjects in photograph treatments were more likely to stress their ethnic identity over their Ugandan one. We find no evidence that photographs increased ethnic voting because they helped subjects learn who was a coethnic; subjects in photograph treatments were no better at identifying candidates' ethnicities. While we do not claim from the basis of these tests that ballot photographs can never provide ethnic information-indeed, there were a priori reasons to expect that learning would not occur in our study — we can rule out learning as an alternate explanation, providing further evidence of ballot photographs' potential to affect ethnic voting by priming identity.

Our findings have significant theoretical and practical implications. First, we extend research on the "watching eyes" effect to political outcomes, where it has not yet been studied. Second, we contribute to studies of ethnic voting in the developing world by highlighting the priming potential of cues. Despite significant research in the United States (Berinsky \& Mendelberg 2005; Brader et al. 2008; Huber \& Lapinsky 2006; Hurwitz \& Peffley 2005; McConnaughy et al. 2010; Mendelberg 2001; Valentino et al. 2002; White 2007), priming has

\footnotetext{
${ }^{2}$ Subjects also marked ballots for president and district women's MP, but those races are not analyzed here because the contests had no coethnics of subjects (the former) or no ethnic variation among candidates (the latter). Subjects were assigned to the same condition (i.e., photographs vs. no photographs) for all races in which they "voted."
} 
not been integrated into studies of electoral decision-making more broadly. ${ }^{3}$ Further, our conclusions regarding priming are strengthened by the fact that our tests rule out learning as an alternate explanation; most studies of cue effects do not attempt to do so, meaning that many scholars mislabel learning effects as priming (Lenz 2009).

Practically, this paper contributes to a growing literature on ballot design, some of which finds that ostensibly well-intentioned innovations can have unforeseen consequences. The relationship between ballot photographs and ethnic voting might be especially important, given these visuals are most often used in developing settings (Reynolds \& Steenbergen 2006), which also tend to have higher potential for inter-ethnic tensions. In fact, countries that include photographs on ballots have significantly higher ethnolinguistic fractionalization scores and more-fragile states than those not using photographs. ${ }^{4}$ Policy makers including photographs on ballots with aims of increasing autonomous, correct voting might inadvertently be increasing the salience of ethnicity in these potentially volatile settings.

\footnotetext{
${ }^{3}$ For an exception, see Adida (2015).

${ }^{4}$ Comparisons made with ballot data from Reynolds \& Steenbergen (2006). Fractionalization comparison significant at $p=.03$ (.413 vs. .546) (data from Fearon (2003)). Fragility comparison significant at $p=.00$ (5.80 vs. 10.03 , with higher scores indicating more-fragile states) (data from Marshall \& Cole (2014)). Photograph-using countries are also more likely to have experienced significant intrastate violence in the last twenty years (40.0\% versus $27.8 \%$ ), although the difference is not statistically significant ( $p=.23$ ) (data from Pettersson et al. 2015).
} 


\section{Last-Minute Cues: How Ballot Imagery Can Affect Electoral Choices}

Casting a ballot correctly requires that citizens be able to locate their favored choice on the paper-or, increasingly, screen—and know how to register their choice. However, citizens often face barriers, such as illiteracy and lack of political knowledge, that make correct voting difficult. Some countries allow voters to cast ballots with the help of another individual, but such "assisted voting" is prone to abuse. In the 2013 Zimbabwean election, for example, in which President Robert Mugabe won an unexpectedly easy victory, hundreds of thousands of voters, many of whom were reportedly literate and pressured into accepting "assistance," brought someone with them to cast a ballot (Solidarity Peace Trust 2013).

An alternate strategy for facilitating correct voting, which does not threaten privacy or enable intimidation, is providing visual cues on ballots. Graphics can illustrate how to fill out and cast ballots, while symbols and photographs can represent each candidate, party, or referendum option. An illiterate voter can then find a preferred party by locating its symbol, or a preferred candidate by recognizing his or her face. In systems using such images, campaign paraphernalia often prominently display candidates' faces and parties' symbols, and rallies and advertisements exhort supporters to place their mark next to a particular symbol.

Democracy-promotion organizations therefore often recommend including visual elements on ballots, especially in contexts with widespread illiteracy (ACE Electoral Knowledge Network 2011). According to data collected by Reynolds and Steenbergen (2006), some 29\% of sampled countries $(N=102)$ use ballot photographs, while $62 \%$ use symbols. Indeed, they find that countries that use either type of visual have significantly lower literacy rates than those that do not. 
However, while ballot cues can act as heuristics, they also have the potential to affect citizen preferences directly, often in seemingly unintended ways (Reynolds \& Steenbergen 2006; Smith et al. 2009). First, citizens might respond positively or negatively to symbols, thereby affecting assessments of the options those images represent. For example, person-on-the-street interviews conducted during Uganda's 2005 referendum on the return to multipartyism suggested some voters were making choices based on their feelings towards options' symbols. "You need a tree [representing multipartyism] to build a house [representing retention of the noparty system], so I chose the tree," one voter said. "[A]ll foods come from the tree...The house can easily collapse while a tree will be there forever." "I ticked the house because it looked good," another said. "I do not understand what it means" (Nyakairu \& Glauser 2005). ${ }^{5}$ Others have found that ballot colorations can affect vote choice (Garrett \& Brooks 1987).

Visual images can also prime. Certain criteria might increase in salience when the ballot draws attention to them (Katz et al. 2011; Meredith \& Salant 2013; Reynolds \& Steenbergen 2006). For example, voters might weight gender more considerably when candidate photographs are present; colorful party symbols, on the other hand, might pull them in the direction of copartisans [publication by authors]. Certainly, many of these effects will be ephemeral. However, as Reynolds and Steenbergen note, "[s]ince the effect is immediate-symbols influence the vote choice right in the polling place-it does not matter that it is usually shortlived" (2006, p. 580). Theoretically, such effects could swing elections.

\footnotetext{
${ }^{5}$ For a discussion of how symbol assignment to candidates in Tanzania affected electoral outcomes, see Molnos (1967).
} 


\section{Ballots and the "Watching Eyes" Effect}

Among the ways that ballot imagery might affect voting — and one that has, to our knowledge, gone uninvestigated - is by affecting support for coethnics. Presumably, policymakers include images such as candidate photographs on ballots to facilitate autonomous, correct voting, and not to affect ethnic voting. However, there are theoretical reasons to expect that photographs might increase the number of people voting along ethnic lines.

We argue that photographs might prime voters to weight identity considerations more heavily. Cues have the potential to lead decision-makers to downplay, or even possibly ignore, some criteria, in favor of something else (Iyengar \& Kinder 1987). Politicians frequently attempt to shift emphases away from issues on which they feel disadvantaged, and towards those on which they would prefer voters focus (Iyengar \& Simon 2000; Petrocik 1996). Ethnic sentiments, in particular, can be primed by instrumentalist politicians (Bates 1974; Chandra 2004; Ferree 2011; Posner 2005). Further, priming could occur without the intention of any particular actor; research has shown that the presence of a national flag (Carter et al. 2011) or the type of building in which people vote (Berger et al. 2008) can affect electoral choices. Of course, cues might not be able to prime individuals to consider criteria that they had previously considered completely irrelevant. ${ }^{6}$ However, given the politicization of ethnicity in many countries using ballot photographs, we can expect that the potential for priming identity often exists. Cues, then, might cause individuals to weight identity more than alternate decision-

${ }^{6}$ With regard to identity, constructivist scholars tend to argue that elites cannot necessarily activate every identity category of their choosing (Chandra 2012). Rather, it is more possible to mobilize around categories previously considered somewhat politically relevant. 
making criteria, such as incumbent performance, partisanship, and policy platforms, which are also often relevant to voters, even in settings where ethnicity is salient (Bratton et al. 2012; Conroy-Krutz 2013; Hoffman \& Long 2013; Keefer 2010; Wantchékon 2003; Weghorst \& Lindberg 2013; Youde 2005).

Photographs might prime identity considerations by increasing voters' motivations to engage in pro-social behavior, which favors in-group loyalty. The inclusion of photographs of candidates' faces means that, when voters mark their ballots, they will see multiple pairs of eyes. While such a feature likely seems anodyne to ballot designers, research in myriad areas, including behavioral economics, neuroscience, and evolutionary biology, suggests distinct, predictable responses to the presence of eyes. Many animals rely on non-vocal communication, much of which occurs through the eyes (Emery 2000). For example, dogs are significantly less likely to try to steal food if they make eye contact with their owner (Call et al. 2003); chimpanzees behave similarly with peers (Hare et al. 2001). Humans, in particular, have long used such forms of communication, and evolutionary psychologists suggest that early humans who could learn appropriate cues from potential competitors' and cooperators' eyes enjoyed survival advantages (Cosmides \& Tooby 1992). Over time, humans developed a neural architecture dedicated to taking cues from eyes, to the extent that many researchers argue that recognition of others' gaze generates involuntary, automatic responses (Emery 2000; Haxby et al. 2000).

Among the most-recognized responses to the presence of "watching eyes" is increased emphasis on other-regarding preferences. For example, "watched" subjects make significantly larger distributions in dictator and public goods games (Burnham 2003; Burnham \& Hare 2007; Haley \& Fessler 2005; Nettle et al. 2012), as well as in real-world charity drives (Ekström 2011; 
Powell et al. 2012). Others have found that eyes can increase rates at which individuals clean up others' litter (Francey \& Bergmüller 2012) and donate for drinks provided in a university faculty common area (Bateson et al. 2006), while decreasing rates at which they themselves litter (Bateson et al. 2013; Ernest-Jones et al. 2011) or even steal bicycles (Nettle et al. 2012). The implications of such findings are broad, but to our knowledge, they have not been extended to politics.

The mechanism behind the "watching eyes" effect is somewhat unclear. Eyes might make individuals more likely to consider the reputational costs of being caught while engaged in anti-social behavior (e.g., littering, free-riding), while they also might make individuals consider the costs of other forms of sanctioning that might occur for breaking injunctive norms (e.g., against theft) (Bateson et al. 2013). Regardless of the mechanism, it is important to note that experimental subjects in "eyes-watching" treatments should have no reason to consciously believe they are being monitored more than those in a control—-these studies only involve images of eyes, never an actual, present observer ${ }^{7}$ - leading some to conclude that the effect of eyes is neurologically hard-wired (Burnham \& Hare 2007).

In many contexts, a salient form of pro-social behavior is loyalty to an ethnic group. Norms might suggest that coethnics favor one another in social interactions and material exchange (Foddy \& Yamagishi 2009; Michelitch 2015), while individuals will come to expect preferential treatment from ethnic brethren (Jetten et al. 1996). Such in-group solidarity can emerge for various reasons, such as a desire to avoid exploitation by another group (Hechter 1975) or to establish welfare-enhancing reciprocal exchange (Ekeh 1974). Individuals who favor

\footnotetext{
${ }^{7}$ In one study, the eyes were not even human. Rather, they belonged to the famed "Kismet" robot at the Massachusetts Institute of Technology (Burnham \& Hare 2007).
} 
coethnics will accrue reputational benefits, and thus potentially receive reciprocal favors from coethnics, or be subject to sanctioning for violating norms against "defection" (i.e., favoring members of another group). Habyarimana et al. (2009) find evidence of such favoritism in laboratory experiments in Uganda: there, subjects playing a version of the dictator game made larger donations to coethnics than they did to non-coethnics when their identity was known to other players. Importantly, they also find that subjects only adhere to such norms when their behavior is observable by others: in an anonymous version of the same game, coethnic favoritism disappeared.

In the context of electoral behavior, individuals might be expected to vote for coethnics, when such candidates are available, while politicians are expected to direct benefits to ethnic brethren (Chandra 2004). Given that ballots are generally secret, individuals can violate these norms without fear of reputational costs or direct sanctioning. However, if this non-transparency is threatened, whether by political agents violating ballot secrecy or by cues that give individuals a sense of being watched (e.g., images of eyes), individuals will be more likely to adhere to locally defined pro-social behaviors, and vote for coethnics. Thus, we expect that visual cues on ballots can prime individuals to consider identity, thereby affecting ethnic voting rates. ${ }^{8}$

${ }^{8}$ This literature suggests that exposure to eyes will increase ethnic voting, regardless of whose eyes are being shown. We might expect the effect to be even stronger when the eyes belong to a coethnic, since individuals might find it especially psychologically difficult to vote against a coethnic when one is, essentially, staring them in the face. However, since our photograph treatments only included images of actual candidates-doing otherwise would have limited ecological validity and been ethically problematic - we are not able to study the possible differential effects of ethnic vs. non-coethnic eyes. 
Cues have the potential to do more than prime identity considerations. Considering — and ruling out—potential alternate explanations for observed effects is important for establishing that priming has occurred (Lenz 2009). Notably, cues can also provide new information. Theoretically, there are reasons to expect that photographs might help voters distinguish between coethnic and non-coethnic candidates, thus facilitating ethnic voting. Several studies have found that facial phenotype conveys ethnic information (Lu et al. 2006; Webster et al. 2004), while political scientists have argued that information about a candidate's ethnic identity is relatively cheap for voters to obtain, since they can ascertain it visually (Chandra 2004). Voters wishing to support a coethnic can use this information, thereby reducing the probability that they vote for a non-coethnic.

Cues might simultaneously prime and inform, but it is important to note that the former might occur even if the latter does not. ${ }^{9}$ While there are theoretical reasons to expect that photographs can convey candidate ethnicity, several factors might limit their informational effects. In many contexts, face alone might not provide sufficient information for voters to assess candidate ethnicity. Further, citizens might have already ascertained candidates' ethnicities by the time they interact with the ballot, at the end of a campaign. However, if priming of ethnic considerations occurs, citizens will weight whatever ethnic knowledge they possess about candidates more heavily, leading to an increase in voting for coethnics. In the following sections, we discuss our strategies for measuring photographs' effects on ethnic voting, as well as those for determining whether any observed differences are attributable to priming and/or learning.

\footnotetext{
${ }^{9}$ Learning without priming is also possible (Lenz 2009).
} 


\section{Case Selection and the Experiment}

\subsection{Country Selection}

We selected Uganda to test our theory, for a number of reasons. First, it has a history of including various elements on ballots. Candidate photographs first appeared on ballots in 1994, and party symbols in 2006. It would not seem particularly odd to Ugandans to mark ballots that included (or excluded) various visual elements. Furthermore, the implications of including certain ballot features are especially relevant in Uganda given variation in practice over time.

Second, ethnicity has been central to Ugandan politics since independence. The country ranks as one of the most ethnically diverse in the world (Posner 2004: 856), with the largest group, the Baganda, comprising only $16.9 \%$ of the population (2002 Census). Other major groups include President Yoweri Museveni’s Banyankole (9.5\%), Basoga (8.4\%), Bakiga (6.9\%), Iteso (6.4\%), and Langi (6.1\%). ${ }^{10}$ Ugandan parties have been structured along regional, ethnic, and religious schisms (Kasfir 1976). Two of the earliest, the Uganda People's Congress (UPC) and the Democratic Party (DP), eventually became associated with Northerners (i.e., Acholi and Langi) and Catholic Baganda, respectively. Ethnic schisms were exacerbated by events such as the abolition of traditional kingdoms in 1966, Idi Amin's violent purges against Acholi and Langi soldiers in the 1970s, and President Milton Obote's brutal counter-insurgency campaign that affected primarily Baganda in the 1980s.

The Movement system, which Museveni established upon his seizure of power in 1986, banned electioneering by parties, ostensibly in an attempt to de-ethnicize politics (Museveni 1997). Following the transition to multipartyism in 2006, Museveni's National Resistance

\footnotetext{
${ }^{10}$ No other group claimed more than $5.0 \%$ of the population; nearly half $(45.8 \%)$ of Ugandans are affiliated with one of these smaller groups.
} 
Movement (NRM) sustained a multiethnic base, though one anchored in Western groups like the Banyankole and Central groups like the Baganda. Opposition parties had even clearer ethnic bases of support (Cheeseman \& Ford 2007). At least prior to the 2011 elections, and a potential realignment amongst some Northern groups (Conroy-Krutz \& Logan 2012), the main opposition Forum for Democratic Change (FDC) performed well among Acholi, Langi, Iteso, and other Northerners, while the UPC and DP remain largely Langi and Baganda parties, respectively.

However, Ugandans have exhibited a willingness to cross ethnic lines during elections (Tripp 2011: 54-6). After all, the two leading candidates in the last three presidential contestsMuseveni and the FDC's Kizza Besigye - are both Westerners from closely related groups. Together, they have won between 94 and $97 \%$ of the vote since 2001, despite the fact that their groups comprise less than $10 \%$ of the population.

This reality—-political salience of ethnicity, but demonstrated willingness to cross ethnic lines in voting — made Uganda an ideal study site. Selection of a case at either extreme —one in which ethnicity is politically unimportant and one in which inter-ethnic schisms are so deep as to prevent any cross-ethnic voting - would likely lead to Type II errors in our attempts to draw generalizable lessons. If ethnicity is not an important electoral consideration, then photographs should have no effect on ethnic voting. On the other hand, if ethnicity is an overwhelming consideration, then no element of ballot design is likely to change rates of ethnic voting. Since

most African electoral competitions fall somewhere between these two extremes-ethnicity being an important, but not completely overriding consideration - an experiment in an area falling close to either would be inadvisable.

\subsection{Experimental Design}


To test the effects of ballot design on outcomes such as ethnic voting, we conducted an experiment in Uganda in the days prior to the country's 2011 elections. Subjects filled out sample ballots to indicate preferences in four contests: president, MP, district chairperson, and district women's MP. ${ }^{11}$ They used separate ballots for each contest, a practice mimicking actual voting in Uganda.

Subjects were randomly assigned to photograph or non-photograph conditions. We also designed the experiment to allow us to test for the effects of party cues on party-based voting; those results are reported separately in [publication by authors]. Therefore, some ballots in each of these conditions included party identifiers (i.e., names and symbols), while others did not, resulting in four distinct ballot types (Appendix A). By randomly varying ballot type, we could be confident that any observed differences in outcomes across treatments could be attributed to the difference in ballot design, rather than to other factors.

Subjects were assigned to the same ballot type for all four contests (e.g., Ballot 4 for president, MP, district chair, and district women's MP, etc.). The information provided across the treatments always accurately portrayed the actual candidates. Given that experiments on cues and ethnicity often use hypothetical candidates (Carlson 2015; Conroy-Krutz 2013;

${ }^{11}$ Each of Uganda's 111 districts elects a chairperson. In addition, there is a separate MP seat reserved in each district for women. Parliamentary and district elections follow first-past-thepost rules in single-member districts. Presidential and parliamentary elections were held on February 18, and district elections on the 23rd. 
Dunning \& Harrison 2011; Hoffman \& Long 2012) our design offers significant advantages in terms of ecological validity. ${ }^{12}$

Early in the interview, subjects were asked to fill out the mock ballots, in private. ${ }^{13}$ They then placed their ballots in envelopes, which were serialized for later matching with de-identified completed questionnaires.

\subsection{Site Selection}

The experiment was conducted in one parliamentary constituency. Given our interest in ethnic voting, we needed an area in which the candidate pool and electorate were both ethnically diverse. Soroti County, in the Teso Sub-Region, fit both criteria. It is ethnically divided$69.1 \%$ is Iteso, while most of the remainder (29.1\%) is Kumam (2002 Census) - and we

${ }^{12}$ Our ballots did differ from actual ones, by lacking the official Electoral Commission seal and by being marked as "Sample Ballots." Subjects were also reminded at the beginning and close of the survey that the ballots they marked were not real. We did not want any subjects to eschew casting a real ballot because they thought they had done so through our experiment.

${ }^{13}$ Subjects might have been able to see enumerators or others while they marked their ballots, but their choices were, by design, non-transparent. Any violations of these rules - and none were reported by enumerators - should have been orthogonal to the treatment. Therefore, the only between-treatment source of variation in subjects' sense-consciously or not-of being "watched" as they made their choices was the presence of candidates' photographs. 
identified two contests there in 2011-MP and district chairperson - that included Kumam and Iteso candidates. $^{14}$

In the precolonial era, relations between Iteso and Kumam, who speak different languages, were often hostile, with frequent cattle-raiding (Vincent 1977). In recent years, the Iteso-Kumam division has been politically salient. In the last presidential election before our experiment (2006), Besigye (FDC) won at every polling station in Soroti County, but he did best in Kumam areas, and there is a significant, positive correlation between Besigye share at a polling station and Kumam share $(r=.371, p=.00, N=101$ stations $) .{ }^{15}$

In the 2006 MP election, the leading Kumam candidate-Peter Omolo (FDC)—ran strongest in Kumam areas, and there is a positive, significant relationship between Omolo's share at each polling station and Kumam share in that polling station's parish $(r=.609, p=.00)$. However, some significant portion of Iteso voters was willing to support a Kumam candidate; Kumams represent less than one third of the constituency's population, yet Kumam candidates

${ }^{14}$ In the MP contest, Kumam candidates included Peter Omolo of the FDC (the incumbent), Vincent Enomu (NRM), and Simon Peter Ebitu (independent), while Iteso candidates included Engirot Lawrence Okae (UPC), Raphael Okoropot (DP), Jimmy Oriokot (People's Progressive Party, PPP), and independents Samuel Anyolo, John Lule, and William Obit. In the district chairperson contest, George Michael Egunyu (NRM) and Napoleon Martina Oliba (UPC) were Kumam, while Daniel Ediau (FDC), and independents Leonard Otekat Ekapu, George William Okwaput, and Jorem Obicho Opian were Iteso. All candidates for district women's MP were Iteso, while there were no Kumam or Iteso presidential candidates.

${ }^{15}$ Ugandan counties are divided into sub-counties, then parishes. Ethnic data were only available at the parish level; Soroti parishes in 2006 had between two and six stations apiece. 
won $72 \%$ of the vote. ${ }^{16}$ To measure more precisely rates of ethnic voting in Soroti County's recent past, we utilize King's (1997) ecological inference method to generate point estimates of the share of Kumams and Iteso voting for each candidate at each polling station. ${ }^{17}$ Not surprisingly, candidates performed better with coethnics. ${ }^{18}$ The estimated mean share of Kumams voting for Kumam candidates was $.88(\mathrm{SD}=.006)$, while Kumam candidates' estimated mean share among Iteso was $.65(\mathrm{SD}=.002) .{ }^{19} \quad$ The estimated mean shares for the Iteso candidates $^{20}$ were $.33(\mathrm{SD}=.002)$ among coethnics and $.09(\mathrm{SD}=.005)$ among non-coethnics. In sum, ethnicity appears to have political salience in Soroti, yet schisms between Kumam and Iteso residents are not so stark as to prevent cross-ethnic voting.

\subsection{Subject Selection}

Subjects were selected through a multi-stage design. The first involved the selection of forty-five Enumeration Areas (EAs) in Soroti County, with probability of selection directly proportional to an EA's population (2002 Census). Selected EAs cover all seven sub-counties

\footnotetext{
${ }^{16}$ Omolo won 62\%, while the other Kumam candidate-Ateker Ejalu—won $10 \%$.

${ }^{17}$ Since there are not reliable estimates of turnout at each station, the analysis assumes no significant differences across ethnic groups in turnout rates.

18 The exception was Ateker, whose estimated mean share was higher among Iteso (.12, $\mathrm{SD}=.001)$ than among fellow Kumams (.05, $\mathrm{SD}=.003)$. This was likely due to the fact that Kumam support is particularly strong for the FDC, and Ateker was the NRM candidate.

${ }^{19}$ Means weighted by votes cast per station.

${ }^{20}$ Samuel Anyolo (independent) and Engirot Lawrence Okae (UPC).
} 
and nineteen of the twenty-six parishes in Soroti County (Appendix B). Within selected EAs, interviewers selected households via a random-walk pattern, while subjects were recruited from selected households using a Kish grid. Subjects had to be at least eighteen years old, a Ugandan citizen, and able to participate in an interview conducted in English, Iteso, or Kumam. 93.4\% of those selected consented and completed the survey. Surveys were conducted between 10 February and 17 February 2011.

We are not aware of any specific issues that would suggest that our results should not be generalizable (Kam et al. 2007), though we cannot be certain about the extent to which they apply to other populations. Soroti County is somewhat poorer and slightly less literate than the rest of Uganda (2002 Census), and our sample is not fully representative of Soroti County. ${ }^{21}$ Regardless of the specific sample employed, our theoretical argument and experimental evidence have general implications.

Finally, we check for statistical balance across conditions in our generated sample for observables that we did not expect would be affected by the treatments, but which could

${ }^{21}$ Serial numbers on questionnaires were used to select subjects $(N=707)$, using Kish grid requirements. However, we also used serial numbers to assign treatments, which resulted in an unexpected interaction. Namely, some positions on the grid did not have equal probabilities of assignment to each treatment. Appendix $\mathrm{C}$ includes details of this issue and our devised strategy for addressing it. Analyses only include subjects from grid positions that had an equal probability of being assigned to comparison conditions $(N=256)$. While this maintains the experimental design, it costs statistical power and places some limitations on external validity, since the analysis population is not representative of the local population at the within-household level. 
theoretically affect outcomes of interest. These variables include demographics (sex, age, wealth, ethnicity, education); 2006 presidential vote; need for assistance when voting in the previous election; political knowledge; English-language ability; and media consumption. ${ }^{22}$ The lack of significant differences between photograph and non-photograph conditions (Appendix D) suggests that any observed treatment effects were not likely driven by confounders.

\section{Effects of Cues on Ethnic Voting}

Our primary dependent variable is total votes for coethnics. ${ }^{23}$ Local research assistants coded the ethnicity of all relevant candidates. ${ }^{24}$ We then matched subjects' self-reported "tribal identity" against those of candidates for whom they voted. For each contest, subjects were coded as 1 if they voted for a coethnic candidate and 0 if they voted for a non-coethnic candidate or did not vote. ${ }^{25}$ The indicators for coethnic voting in the MP contest and in the district chairperson contest were summed to produce the overall measure of ethnic voting.

We find that subjects in the photograph condition voted for an average of .94 $(95 \% \mathrm{CI}$ $[.80,1.08])$ coethnics across the two races, while those in the non-photograph condition voted for .74 (95\% CI $[.61, .87])(t=2.05, p=.04)$; in other words, including photographs increased ethnic voting by $27.0 \%$. To obtain more precise measures of photographs' effects, we run an ordered logit model with a number of controls, including measures of whether ballots included party

\footnotetext{
${ }^{22}$ For details on these variables, and the logic for their inclusion, see Appendix D.

${ }^{23}$ English-language wordings for relevant questions are reported in Appendix E, while descriptive statistics for dependent variables are presented in Appendix F.

${ }^{24}$ In cases of inter-coder discrepancy, candidates' family members were interviewed.

${ }^{25}$ Our results are similar when subjects who did not vote are dropped.
} 
symbols, and subject age, sex (female), ethnicity (Iteso), and ability to read English. The coefficient on the photographs indicator is positive and significant $(p=.02)$ (Table 1, Column A). ${ }^{26}$

\section{[Table 1 goes around here]}

\section{Evaluating Explanations: Priming or Learning?}

In the next sections, we evaluate whether the observed effects of ballot photographs on ethnic voting can be attributable to priming, learning, or both. Evaluating causal mechanisms is difficult with respect to inference (Green et al. 2010; Imai et al. 2011). We do, however, identify suggestive evidence of mediation, by examining whether our treatments influence ethnic salience or knowledge, the hypothesized mediating variables.

\subsection{Priming}

Our theory holds that ballot photographs can increase ethnic voting by priming individuals to consider ethnicity more in their electoral decision-making. We attempt to measure priming by examining differences in ethnic identification across treatments. ${ }^{27}$ If photographs

${ }^{26}$ These results hold in the absence of the subject-level controls (Appendix G). In addition, we find no significant difference in the effects of photographs on ethnic voting depending on the presence of party cues. We run a model in which we interact the photograph and party cues indicators. The coefficient on the photograph indicator remains significant, but the interaction is not (Appendix H, Column A).

${ }^{27}$ Our strategy is thus similar to White (2007), who measures how racial cues affect in-group identification and, in turn, attitudes. 
prime ethnic considerations, and thus increase support for coethnics, we should also observe treatment-induced differences in the strength of subjects' ethnic attachments. Subjects who filled out ballots with photographs would demonstrate stronger ethnic sentiments than those who did not.

To measure these sentiments, subjects were asked to weigh the value of their ethnic versus national identities. Individuals had the option of identifying as "only Ugandan" (coded as 0), "more Ugandan than [ethnic group]" (1), "equally Ugandan and [ethnic group]" (2), "more [ethnic group] than Ugandan" (3), and "only [ethnic group]" (4). ${ }^{28}$ Higher values indicate greater ethnic salience. Eifert et al. (2010) use the same type of question to assess the effects of political competition on ethnic salience in Africa. ${ }^{29}$

Subjects in the photograph condition (2.14) (95\% CI [1.97, 2.32]) were significantly more likely than those in the non-photograph condition to emphasize their ethnic identity over their national one (1.88) (95\% CI [1.68, 2.08]) (Wilcoxon-Mann-Whitney test, $z=1.89, p=.06)$. The average score on the ethnic-identity measure is $13.8 \%$ higher amongst those who received ballots with photographs. Ordered logit analysis with controls also produces a positive, significant coefficient on the photograph indicator $(p=.05)$ (Table 1, Column B). In sum, the evidence provides support for our argument that cues can affect voting by priming ethnic identity.

${ }^{28}$ We recoded fourteen individuals who answered "don't know" to this question as "equally Ugandan and [ethnic group]." However, the results are similar if we exclude these individuals.

${ }^{29}$ Although they do not reference "priming," one of their possible pathways through which electoral competition could increase ethnic salience — through politicians' playing of the "ethnic card"-might constitute priming. 


\subsection{Learning as an Alternate Explanation}

Given that priming and learning can be observationally equivalent, it is important to consider the latter as a possible alternate explanation for the effects of ballot photographs on ethnic voting. A priori, we had several reasons to expect that ballots would not help subjects learn candidates' ethnicities. First, photographs simply might not convey much ethnic information in many contexts. Images might be too small, or phenotypical differences between groups not sufficiently significant. Indeed, there is evidence that photographs are not tremendously useful as indicators of ethnicity in Uganda; subjects in Habyarimana et al.'s (2009) experiments only correctly identified others' ethnicities from photographs about $29 \%$ of the time (p. 54). ${ }^{30}$

Second, voters in the real world mark ballots after a campaign, during which they have often been bombarded with rallies, advertisements, and personal discussions about candidates. After such a period, learning candidates' identities from ballots might be unlikely because of a ceiling effect. Studies on ballots' potential as information-providers should therefore be conducted near campaigns' end; those conducted earlier are likely to find effects that will be significantly greater than are likely to be found in actual voting booths. For this reason, we conducted our study within a week of the election, which further minimized the likelihood of learning, while also increasing ecological validity.

\footnotetext{
${ }^{30}$ However, it is important to note that their study was conducted in a different context (i.e., Kampala), which is significantly more diverse, with a subject pool that included few Iteso and Kumams.
} 
To check on the possibility that learning did occur in our study, we measure subjects' post-treatment knowledge of candidates' ethnic identities. After subjects had "cast" their ballots, they were shown blank ballots, of the same type they had just been asked to complete. They were then asked a series of questions about each candidate. ${ }^{31}$ In other words, subjects in the photograph conditions were looking at photographs both when they marked their ballots and again when asked about the ethnicity of each candidate, while those in non-photograph conditions never saw candidate photographs at any stage in the process. Subjects were asked to identify each candidate's ethnicity. Correct answers were coded as 1 , and incorrect answers or “don't know" responses as 0. These scores were then summed for all fifteen MP and district chair candidates.

We find no significant difference in subject knowledge of candidate ethnicity across conditions. The mean knowledge scores for photograph and non-photograph treatments were 8.08 (95\% CI $[7.52,8.63])$ and 8.04 (95\% CI $[7.48,8.60])$, respectively $(t=.09, p=.93)$. Similarly, OLS regression including controls yields null results $(p=.92)$ (Table 1, Column C). ${ }^{32}$ These null results remain when we disaggregate our outcome measure into knowledge of different types of candidates: photographs did not help subjects learn about only their preferred

${ }^{31}$ We instructed interviewers to point to the relevant candidate as they asked each question; protocols stipulated that interviewers provide no assistance when subjects marked ballots.

${ }^{32}$ A similar analysis including candidates for women's MP (i.e., a pool of twenty-three, rather than just the fifteen MP and district chair candidates) also yields null results $(t=.31, p=.76)$. 
candidates, only non-preferred candidates, only major party candidates, or only non-major party candidates (Appendix H, Columns B-E). ${ }^{33}$

Despite our study's timing, our null results do not appear to be driven by ceiling effects. While most subjects in the control had the necessary information to vote for a coethnic if they wanted to $-91 \%$ could identify at least one coethnic in the MP race, while over three-quarters $(80 \%)$ could do so for the district chair race-there was substantial room for knowledge improvement among that group. ${ }^{34}$ Also, the difference between the photograph and nonphotograph groups in mean knowledge is negligible (.03), so we would expect null results even with a larger sample. ${ }^{35}$

${ }^{33}$ In our study, $97 \%$ of subjects could correctly identify at least one coethnic, which is a requirement for priming ethnicity. Voters do not need to be fully informed about all, or even most, candidates' ethnic identities for a priming mechanism to work. Rather, the only necessary condition, in addition to ethnicity being a politically relevant factor, is that the voter must know the ethnic identity of at least one coethnic candidate. Raising (or lowering) the salience of ethnicity in the voter's electoral decision-making process can then increase (or decrease) the probability that the voter supports that candidate.

${ }^{34}$ Subjects who received ballots with only candidates' names could identify the ethnicity of an average of 7.8 of the fifteen MP and chair candidates.

${ }^{35}$ Our results also hold across all models regarding vote choice and candidate knowledge if we treat subject-election as the unit of analysis. These analyses treat each race as a distinctive choice facing voters and each candidate pool as a separate entity about which voters might have varying levels of knowledge (Appendix I). 
Our findings should not be interpreted as suggesting that ballot photographs never provide information about candidate ethnicity. Theoretically, such effects are possible if faces do convey more distinctive information about ethnic identity than they might have in the context of Soroti, or if citizens cannot or choose not to learn about candidates prior to interacting with the ballot. However, we are able to rule out learning in this case, which adds further weight to our argument about the potential priming effects of ballot photographs.

\subsection{Alternative Explanations and Additional Evidence on Cues and Ethnic Voting}

In this section we discuss additional analyses to further probe whether priming is the likely cause of the increased ethnic voting we observe.

First, we consider whether subjects might be using photographs to locate pre-preferred candidates. Under this scenario, subjects would not be learning about candidates from the photographs. Rather, they would already have been planning to vote for a coethnic, and the photographs would guide them toward that choice better than text alone. Subjects without photographs would be more prone to error. Given our finding that exposure to photographs increased ethnic salience, this does not seem a likely explanation; however, we check on it through various strategies. Although we cannot test this possibility directly without a pretreatment measure of candidate preference, we can examine whether 1) photographs improved subjects' abilities to read the ballot, 2) effects were larger amongst those more likely to need photographs to locate pre-preferred candidates, and 3) photographs increased the probability that subjects voted for candidates who were in line with their likely pre-treatment preferences. We see no evidence that photographs increased subjects' likelihood of marking the ballots (Appendix H, Column F) or their reported ease of reading the ballots (Appendix H. Column G). These 
objective and subjective measures do not suggest that photographs significantly improved subjects' abilities to use the ballots. We also see no evidence that the treatment's effects were larger for the subjects most likely to need photographs to help them locate pre-preferred candidates, as we find no significant heterogeneous effects on the basis of literacy or political sophistication (Appendix H, Columns H \& I).

If visual cues alter vote choice because they help individuals identify pre-preferred candidates, then we should expect greater alignment between subjects and their vote choice along multiple dimensions when they receive ballots with such cues. However, photographs had no effect on the match between subjects' stated party preferences and the party they voted for (Appendix H, Column J). ${ }^{36}$ Likewise, an alternate visual cue, party symbol, did not increase coethnic voting (though it did increase partisan voting) [publication by authors]. Visual cues do not seem to increase "correct voting" per se, but rather they seem to improve alignment only on along the particular dimension being emphasized, as one might expect if priming were the mechanism.

This criteria-specific effect becomes more apparent when different criteria are in conflict. According to our theory, in circumstances where coethnicity and copartisanship cross-cut,

${ }^{36}$ Since partisan identification is measured post-treatment, it is possible that responses are biased. Reported past behavior is less likely to be biased by treatments, and thus we also asked subjects to identify how they voted in 2006 in the MP race. Again, we find no relationship between photographs and the likelihood that a subject voted for the same party in both 2006 and 2011 (Appendix H, Column K). And photographs also do not affect the probability that a subject who voted for Omolo - the only major-party candidate to appear on the ballot in both elections-in 2006 did so again in 2011 (Appendix H, Column L). 
photographs should make ethnicity more salient and increase the probability of ethnic voting, at the expense of partisan voting. Thus we should see an increase in ethnic voting and a decrease in partisan voting. Similarly, party cues should prime partisanship and increase partisan voting at the expense of ethnic voting.

We test these predictions by examining, by itself, the district chairperson contest, in which the two major-party candidates came from different ethnic groups. ${ }^{37}$ There, a Kumam candidate (George Michael Egunyu) stood for the NRM, and a member of the Iteso group (Daniel Ediau) was the candidate of the FDC. An analysis on cross-pressured subjects (i.e., those who could vote for a copartisan or coethnic major-party candidate, but not both) demonstrates that photographs increased coethnic support and decreased copartisan support. In other words, photographs caused individuals to support non-copartisan, coethnic candidates (Appendix H, Column M). Furthermore, in other research based on these experimental data [publication by authors], we find that party identifiers significantly increased partisan voting and decrease ethnic voting among cross-pressured individuals. ${ }^{38}$ Taken together, these results suggest that the type of cue matters for the type of voting that results. Cues caused individuals to change their preferences based on which candidate attribute is highlighted.

${ }^{37}$ We define major-party candidates as those from the NRM and FDC. Together, these two parties claimed $95.7 \%$ of the presidential vote in Soroti District in 2011. Both major-party candidates for MP were Kumam.

${ }^{38}$ We caution that we cannot be certain that these changes in copartisan voting occurred because of switches from non-coethnic to coethnic candidates, or that changes in coethnic voting occurred because of switches from non-copartisan to copartisan candidates. We also note that our measure of subject partisanship could have been affected by post-treatment bias. 
Finally, our theory suggests that exposure to photographs will cause individuals of different ethnicities to prefer different candidates. That is what we find. When we interact the photograph indicator with an indicator for ethnic group membership, we find that photograph remains a positive and significant predictor of ethnic voting, but the interaction term is not significant (Appendix H, Column N). In other words, there is no significant difference between ethnic groups in the effect of photographs on ethnic voting. This suggests that photographs caused Kumam subjects to prefer Kumam candidates and Iteso subjects to prefer Iteso candidates, rather than causing Kumam and Iteso subjects to prefer the same candidates irrespective of ethnicity. ${ }^{39}$

In sum, the effects of photographs on ethnic voting seem to be the result of the specific ethnic identities they invoke and not due to generic changes in candidate preferences. Furthermore, photographs increased the identity salience. The evidence presented here indicates that photographs on ballots increased ethnic voting, which most likely occurred because the photographs primed ethnic considerations.

\section{Conclusion}

Democracy requires that all citizens have the ability to express their political preferences, freely and autonomously, on election day, and that those preferences will be recorded accurately.

\footnotetext{
${ }^{39}$ Furthermore, our results are not being driven by a particular candidate. When we drop each of the candidates individually, the coefficient on the indicator for photographs is consistently negative. In all fifteen resulting regressions the p-value remains below .10, and in thirteen cases it remains below .05 . These results are notable given the lower power due to smaller sample sizes.
} 
With this in mind, many countries, especially in the developing world, where significant proportions of the electorate have limited literacy and political knowledge, include certain visual elements on their ballots, to augment basic textual instructions and options. The logic behind these features is that they should facilitate electoral participation by those who would otherwise feel unable, by allowing them to feel more confident that they can register their choices without error. There is a possibility, however, that these elements not only facilitate the registering of voters' preferences, but also shape preferences in potentially unanticipated ways.

We hypothesize in this project that the inclusion of certain elements-specifically, candidate photographs — on ballots will impact rates of ethnic voting, a topic of central concern in many developing countries. Photographs have the potential to prime ethnic considerations, by encouraging pro-social behavior and actions conforming with prevalent norms, such as supporting coethnics. In short, photographs could make it more likely that individuals weight ethnic criteria more heavily that alternate decision-making criteria, such as partisanship or incumbent performance.

To test our hypotheses on the effects of ballot design on ethnic voting, we conducted a survey experiment in rural Uganda just days before the country's February 2011 general elections. We find that photographs on mock ballots increased ethnic voting rates by $27.0 \%$, and that subjects in the photograph condition were subsequently more likely to stress their ethnic identity, rather than their Ugandan one. Finally, we can rule out learning as an alternate explanation for these effects, as photographs do not seem to have increased subjects' knowledge of candidates' ethnic identities.

Our study has a number of important theoretical and practical implications. First, we situate our study of ballot design in a broader literature on the effects of cues on decision-making 
and demonstrate that priming can be responsible for variation in ethnic voting in the developing world. A significant literature has focused on priming effects in advanced democracies, but such a focus has been largely absent from the developing world (cf. Adida 2015). Those studies on how brief stimuli can affect ethnic voting have typically assumed that such cues help voters learn about candidate ethnicity and/or alternate decision-making criteria (Conroy-Krutz 2013; Dunning \& Harrison 2011; Hoffman \& Long 2013); they have not considered and ruled out possible priming effects, which is important, given that cues can theoretically have both effects (Lenz 2009). Further, our study measures priming directly, by examining how cues affect ethnic salience, which has not been done in other studies in the developing world.

Next, practitioners must consider the full range of possible effects of ballot design, including ostensibly unintended ones. Experimental studies in the context of the developing world - the very places where elaborate ballots are most common — are lacking, and thus our knowledge of the full benefits and costs of including visual elements, such as party symbols and candidate photographs, on ballots is limited. In an observational study, Reynolds and Steenbergen (2006) find that elaborate ballots are not associated with significantly lower spoilage rates in contexts of low literacy, leading them to ponder whether the costs associated with such design, in terms of the financial expense of printing intricate, color ballots and the possibility that cues could affect voters' choices, are justifiable. Our findings lend additional weight to such cautions: interventions intended to strengthen democracy by improving election quality and facilitating autonomous participation might also be encouraging individuals to emphasize ethnic attachments over other potential decision-making criteria, such as incumbent performance and policy positions. 


\section{Works Cited}

ACE Electoral Knowledge Network. 2011. Ballot paper design. http://aceproject.org/aceen/topics/vo/voc/voc02/voc02a (accessed October 28, 2014).

Adida, C. 2015. Do African voters favor co-ethnics? Journal of Experimental Political Science $2(1), 1-11$.

Ansolabehere, S., \& Stewart III, C. 2005. Residual votes attributable to technology. Journal of Politics 67 (2), 365-89.

Banducci, S., Karp, J., Thrasher, M., \& Rallings, C. 2008. Ballot photographs as cues in lowinformation elections. Political Psychology 29 (6), 903-17.

Bates, R. 1974. Ethnic competition and modernization in contemporary Africa. Comparative Political Studies 6 (4), 457-84.

Bateson, M., Nettle, D., \& Roberts, G. 2006. Cues of being watched enhance cooperation in a real-world setting. Biology Letters 2 (3), 412-4.

Bateson, M., Callow, L., Holmes, J., Redmond Roche, M., \& Nettle, D. 2013. Do images of 'watching eyes' induce behaviour that is more pro-social or more normative? PLoS One $8(12)$.

Berger, J., Meredith, M., \& Wheeler, S. 2008. Contextual priming. PNAS: Proceedings of the National Academy of Sciences of the United States of America 105, 8846-9.

Berinsky, A., \& Mendelberg, T. 2005. The indirect effects of discredited stereotypes in judgments of Jewish leaders. American Journal of Political Science 49 (4), 845-64.

Brader, T., Valentino, N., \& Suhay, E. 2008. What triggers public opposition to immigration? American Journal of Political Science 52 (4), 959-78.

Bratton, M., Bhavnani, R., \& Chen, T. 2012. Voting intentions in Africa. Commonwealth and Comparative Politics 50 (1), 27-52.

Buckley, F., Collins, N., \& Reidy, T. 2007. Ballot paper photographs and low-information elections in Ireland. Politics 27 (3), 174-81.

Burnham, T. 2003. Engineering altruism. Journal of Economic Behavior and Organization 50(1), 133-44.

Burnham, T., \& Hare, B. 2007. Engineering human cooperation. Human Nature 18 (2), 88-108. 
Call, J., Bräer, J., Kaminski, J., \& Tomasello, M. 2003. Domestic dogs (Canis familiaris) are sensitive to the attentional state of humans. Journal of Comparative Psychology 117(3), 257.

Carlson, E. 2015. Great expectations. World Politics 55(3), 399-422.

Carman, C., Mitchell, J., \& Johns, R. 2008. The unfortunate natural experiment in ballot design. Electoral Studies 27 (3), 442-59.

Carter, T., Ferguson, M., \& Hassin, R. 2011. A single exposure to the American flag shifts support toward Republicanism up to 8 months later. Psychological Science 22 (8), 1011-8

Chandra, K. 2004. Why Ethnic Parties Succeed. Cambridge University Press, New York.

Chandra, K. (Ed.) 2012. Constructivist Theories of Ethnic Politics. Oxford University Press, New York.

Cheeseman, N., \& Ford, R. 2007. Ethnicity as a political cleavage. Afrobarometer Working Paper.

Conroy-Krutz, J. 2013. Information and ethnic politics in Africa. British Journal of Political Science 43 (2), 345-73.

Conroy-Krutz, J., \& Logan, C. 2012. Museveni and the 2011 Ugandan election. Journal of Modern African Studies 50 (4), 625-55.

Cosmides, L., \& Tooby, J. 1992. Cognitive adaptations for social exchange. In Barkow, J., Cosmides, L., \& Tooby, J. (Eds). The Adapted Mind. Oxford University Press, New York.

Dunning, T., \& Harrison, L. 2010. Cross-cutting cleavages and ethnic voting. American Political Science Review 104 (1), 21-39.

Eifert, B., Miguel, E., \& Posner, D. 2010. Political competition and ethnic identification in Africa. American Journal of Political Science 54 (2), 494-510.

Ekeh, P. 1974. Social Exchange Theory. Harvard University Press, Cambridge.

Ekström, M. 2011. Do watching eyes affect charitable giving? Experimental Economics 15(3), $530-46$.

Emery, N. 2000. The eyes have it. Neuroscience and Biobehavioral Reviews 24 (6), 581-604.

Ernest-Jones, M., Nettle, D., \& Bateson, M. 2011. Efects of eye images on everyday cooperative behavior. Evolution and Human Behavior 32 (3), 172-8. 
Fearon, J. 2003. Ethnic and cultural diversity by country. Journal of Economic Growth 8 (2), 195-222.

Ferree, K. 2011. Framing the Race in South Africa. Cambridge University Press, Cambridge.

Foddy, M., \& Yamagishi, T. 2009. Group-based trust. In Cook, K., Levi, M., \& Hardin, R. (Eds.) Whom Can We Trust? Russell Sage, New York.

Francey, D., \& Bergmüller, R. 2012. Images of eyes enhance investments in a real-life public good. PLoS One, 7.

Garrett, J., \& Brooks, C. 1987. Effect of ballot color, sex of candidate, and sex of college students of voting age and their voting behavior. Psychological Reports, 60, 39-44.

Green, D., Ha, S., \& Bullock, J. 2010. Enough already about "black box" experiments. The Annals of the American Academy of Political and Social Science 628 (1), 200- 8.

Habyarimana, J., Humphreys, M., Posner, D., \& Weinstein, J. 2009. Coethnicity. Russell Sage Foundation, New York.

Haley, K., \& Fessler, D. 2005. Nobody's watching? Evolution \& Human Behavior 26, 245-56.

Hare, B., Call, J., Tomasello, M. 2001. Do chimpanzees know what conspecifics know? Animal Behaviour 61(1), 139-51.

Haxby, J., Hoffman, E. A., \& Gobbini, I. 2000. The distributed human neural system for face perception. Trends in Cognitive Science 4 (6), 223-33.

Hechter, M. 1975. Internal Colonialism. University of California Press, Berkeley.

Herrnson, P., Hanmer, M., \& Niemi, R. 2012. The impact of ballot type on voter errors. American Journal of Political Science 56 (3), 716-30.

Herron, M., \& Wand, J. 2007. Assessing partisan bias in voting technology. Electoral Studies 26 (2), 247-61.

Hoffman, B., \& Long, J. 2013. Parties, ethnicity, and voting in African elections. Comparative Politics 45 (2), 127-46.

Huber, G., \& Lapinski, J. 2006. The "race card" revisited. American Journal of Political Science 50 (2), 421-40.

Hurwitz, J., \& Peffley, M. 2005. Playing the race card in the post-Willie Horton era. Public Opinion Quarterly 69 (1), 99-112. 
Imai, K., Keele, L., Tingley, D., \& Yamamoto, T. 2011. Unpacking the black box of causality. American Political Science Review 105 (4), 765-89.

Iyengar, S., \& Kinder, D. 1987. News That Matters. University of Chicago Press, Chicago.

Jetten, J., Spears, R., \& Manstead, A. 1996. Intergroup norms and intergroup discrimination. Journal of Personality and Social Psychology 71(6), 1222-33.

Johns, R., \& Shephard, M. 2011. Facing the voters. Political Studies 59 (3), 636-58.

Kam, C., Wilking, J., \& Zechmeister, E. 2007. Beyond the "narrow data base". Political Behavior 29 (4), 415-40.

Kasfir, N. 1976. The Shrinking Political Arena. University of California Press, Berkeley.

Katz, G., Alvarez, R., Calvo, E., Escolar, M., \& Pomares, J. 2011. Assessing the impact of alternative voting technologies on multi-party elections. Political Behavior 33 (2), 24770 .

Keefer, P. 2010. The ethnicity distraction? Afrobarometer Working Paper.

King, G. 1997. A Solution to the Ecological Inference Problem. Princeton University Press, Princeton.

Lenz, G. 2009. Learning and opinion change, not priming. American Journal of Political Science 53 (4), 821-37.

Lu, X., Chen, H., \& Jain, A. 2006. Multimodal facial gender and ethnicity identification. In: Zhang, D., \& Jain, A. (Eds.), Advances in Biometrics. Springer, Berlin, 55-63.

Marshall, M., \& Cole, B. 2014. Conflict, Governance and State Fragility. Center for Systemic Peace, Vienna, VA.

McConnaughy, C., White, I., Leal, D., \& Casellas, J. 2010. A Latino on the ballot. Journal of Politics 72 (4), 1199-211.

Mendelberg, T. 2001. The Race Card. Princeton University Press, Princeton.

Meredith, M., \& Salant, Y. 2013. On the causes and consequences of ballot order-effects. Political Behavior 35 (1), 175-97.

Michelitch, K. 2015. Does electoral competition exacerbate interethnic or interpartisan economic discrimination? American Political Science Review 109(1), pp. 43-61. 
Molnos, A. An attempt at a psychological analysis of the role of symbols in the Tanzanian elections 1965. In Cliffe, L. (Ed.), One Party Democracy. East African Publishing House, Nairobi.

Museveni, Y. 1997. Sowing the Mustard Seed. Macmillan, London

Nettle, D., Nott, K., \& Bateson, M. 2012. “Cycle thieves, we are watching you." PLoS One 7 (12).

Nyakairu, F., \& Glauser, W. 2005. Why I voted the way I did. Daily Monitor (Kampala) (29 July), p. 4.

Petrocik, J. 1996. Issue ownership in presidential elections, with a 1980 case study. American Journal of Political Science 40 (3), 825-50.

Pettersson, T., \& Wallensteen, P. 2015. Armed conflicts, 1946-2014. Journal of Peace Research 52(4), 536-50.

Posner, D. 2004. Measuring ethnic fractionalization in Africa. American Journal of Political Science 48 (4), 849-63.

Posner, D. 2005. Institutions and Ethnic Politics in Africa. Cambridge University Press, New York.

Powell, K., Roberts, G., \& Nettle, D. 2012. Eye images increase charitable donations. Ethology 118 (11), 1096-101.

Reynolds, A., \& Steenbergen, M. 2006. How the world votes. Electoral Studies 25 (3), 570-98.

Smith, B., Laskowski, S., \& Lowry, S. 2009. Implications of graphics on usability and accessibility for the voter. In: Ryan, P., \& Schoenmakers, B. (Eds.), E-Voting and Identity. Springer, Berlin, 54-74.

Solidarity Peace Trust. 2013. The End of the Road. Solidarity Peace Trust, Durban.

Tajfel, H. 1970. Experiments in inter-group discrimination. Scientific American 223, 96-102.

Tripp, A. 2011. Museveni’s Uganda. Lynne Rienner Publishers, Boulder.

Valentino, N., Hutchings, V., \& White, I. 2002. Cues that matter. American Political Science Review 96 (1), 75-90.

Vincent, J. Colonial chiefs and the making of class. Africa 47(2), 140-59.

Wand, J., Shotts, K., Sekhon, J., Mebane, W. Jr., Herron, M., \& Brady, H. 2001. The butterfly did it. American Political Science Review 95 (4), 793-810. 
Wantchékon, L. 2003. Clientelism and voting behavior. World Politics 55 (3), 399-422.

Webster, M., Kaping, D., Mizokami, Y., \& Duhamel, P. Adaptation to natural facial categories. Nature 428: 557-61.

Weghorst, K., \& Lindberg, S. 2013. What drives the swing voter in Africa? American Journal of Political Science 57 (3): 717-34.

White, I. 2007. When race matters and when it doesn't. American Political Science Review 101 (2), 339-54.

Youde, J. 2005. Economics and government popularity in Ghana. Electoral Studies 24 (1), 116. 
Table 1: Effects of Photographs on Ethnic Voting, Identity, and Knowledge

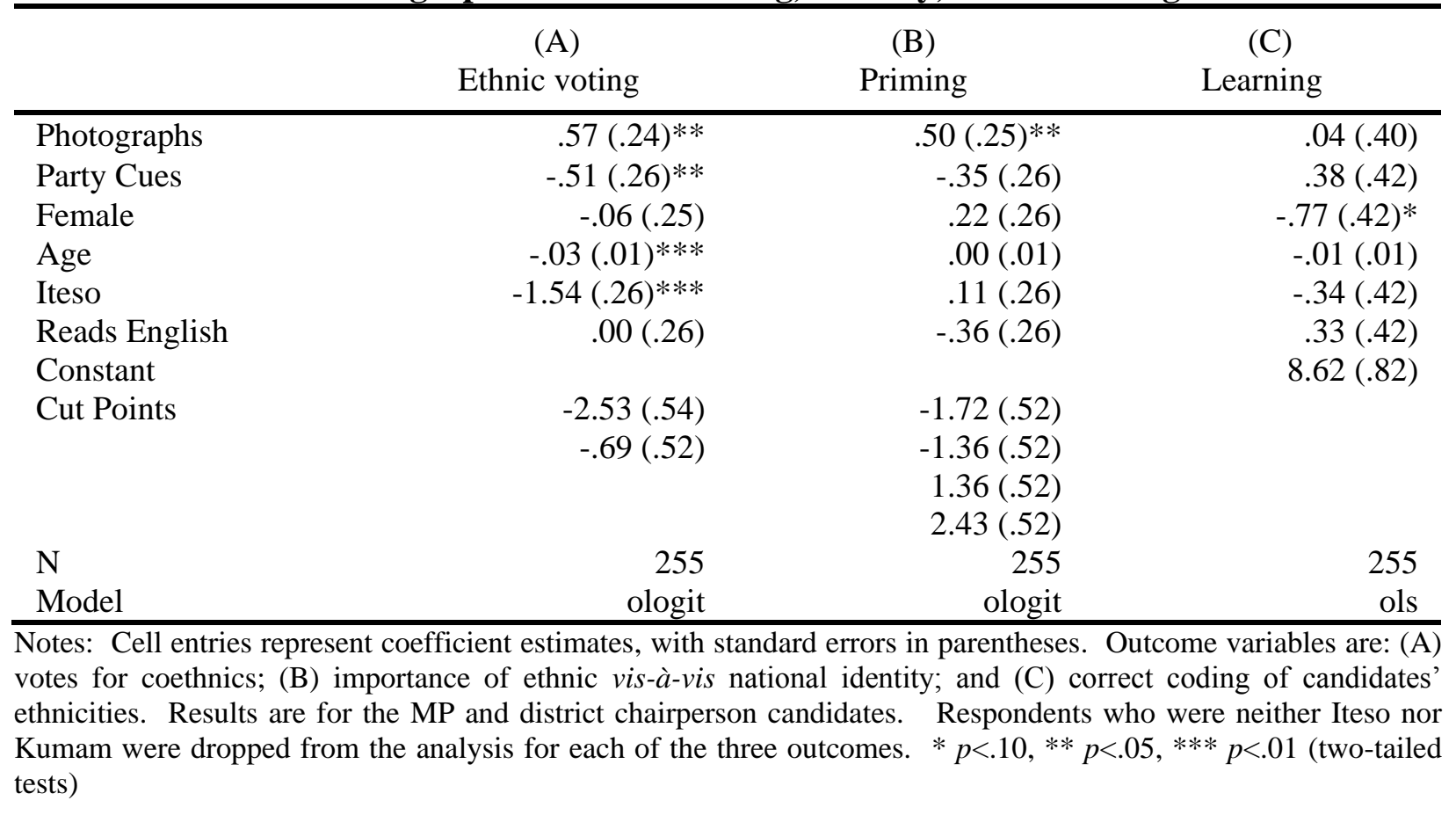

